\title{
COMPARISON OF METHODS FOR MEASURING DRAUGHT FORCE OF TRACTOR DURING SOIL TILLAGE
}

\author{
Milan Buric, Petr Novak, Lukas Benes \\ Czech University of Life Sciences \\ buricm@tf.czu.cz,
}

\begin{abstract}
The aim of this paper is to compare two methods of draught force measurement during field tests. Energy demands of the soil tillage machines are an important factor for the choice of machinery, further development and improvement. A common method of measurement is to use a measuring rod with a tensometric sensor. Using of two tractors is a disadvantage of this method. Inaccuracy is also entered due to rolling resistance of the drawn tractor. A special measuring frame has been developed for the replacement of conventional methods. The frame was developed in cooperation Czech University of Life Sciences in Prague and Bednar FMT companies. Sets of machines were used for the evaluation: the track tractor JD 8320 RT as a pulling tractor, measuring frame located on the tractor's three point hitch, measuring rod frame for frame working control and the wheel tractor NH T7050, and the tines cultivator (Köckerling Exact Gruber Vario, 4,8 m working width). During comparison of the draught force values from the strain gauge load cell located on the new developed measuring frame with the values from the standard device (measuring rod) it was detected that there is not statistical difference between the both methods. The new method with the measuring frame could be used for the purpose of measurement of the draught force (typically for soil tillage machines). We do not have to solve a question about the pulled tractor in this case. This measurement is easier for testing. The testing without the pulled tractor eliminated errors in the application of the classical methods (rolling resistance of the drawn tractor).
\end{abstract}

Keywords: soil, soil characteristic, soil qualities, soil processing, pulling power, polling power measurement.

\section{Introduction}

Mechanical soil resistance is conditioned by many important factors. They are: water content, soil texture, soil compaction, and many others $[1 ; 2]$. The force of soil tillage machines can be affected by parameters. For example, the working width, tool type, working speed and the working depth. The factors influencing the draught force can be the factors dependent on the place. For example, the soil types, soil moisture, soil bulk density and many others [2]. This knowledge of draught force could be a useful tool [3].

Novák et al. [2] conducted measurement of the draught force $t$ with using the load cell with the range of measurement up to $200 \mathrm{kN}$. They used a sensor, which was mounted between two tractors. The second tractor (without in gear) was strapped to the measured tool for soil tillage (tines cultivator). In their study they compared three working speeds. Also, they demonstrated the importance of the soil tillage depth and the soil characteristics (soil type). It is surprising that influence of the working speed has not been demonstrated unequivocally.

McLaughlin and Burtt [4] defined the main influences of measurement errors in their work like tractor and tool vibrations, roughness of soil, differences in the working speed, content of soil moisture, soil differences and variability on the place. Similar results are also described in other studies $[2 ; 3]$.

Kheiralla et al. [5] for experiments used three octagonal ring-analog converters to place on the three-point hitch. The experiment was carried out on sand, clay and loam soil, where they were used in the following devices: the moldboard plow, rotary tiller, disc plow and the disc gate. The same experiment was done by Chen et al. in 2013 [6]. Trials were done at the working speed of $3.2 \mathrm{~km} \cdot \mathrm{h}^{-1}$ on many soil types. The measured values showed that the minimum tensile strength was measured in the soil with coarse sand. By subsequent comparison with the soil loamy-sand the highest values were found in soils sandy-loam.

Determining of compaction of soil profiles requires quick sampling systems to change the conditions of moisture with time. The soil mapping techniques currently used are too costly for soil mapping units[7]. Penetrometers for cone index measurement are commonly used for this purpose, but data collection can take a long time [8]. Cone penetrometer testing (CPT) is a fast and effective system for collecting the soil parameters during a site investigation. When used in conjunction with 
conventional drilling and sampling methods, it provides a complete description of the subsurface conditions.

The aim of this paper is to process and analyse measured data of the draught force tractor utilization of the potential power of the tractor.

\section{Materials and methods}

The experiment took place in Sloveč, near the city Městec Králové in Nymburk district near Prague. The measurement was carried out on October 3. The type of soil was clayey-sandy rendzina on experimental field. Pulling power was carried after harvesting of sugar beets and aerating the soil before the subsequent trailed cultivator Exaktgrubber-Vario. There were a lot of sugar beets on the field in form of rest (Fig. 1).

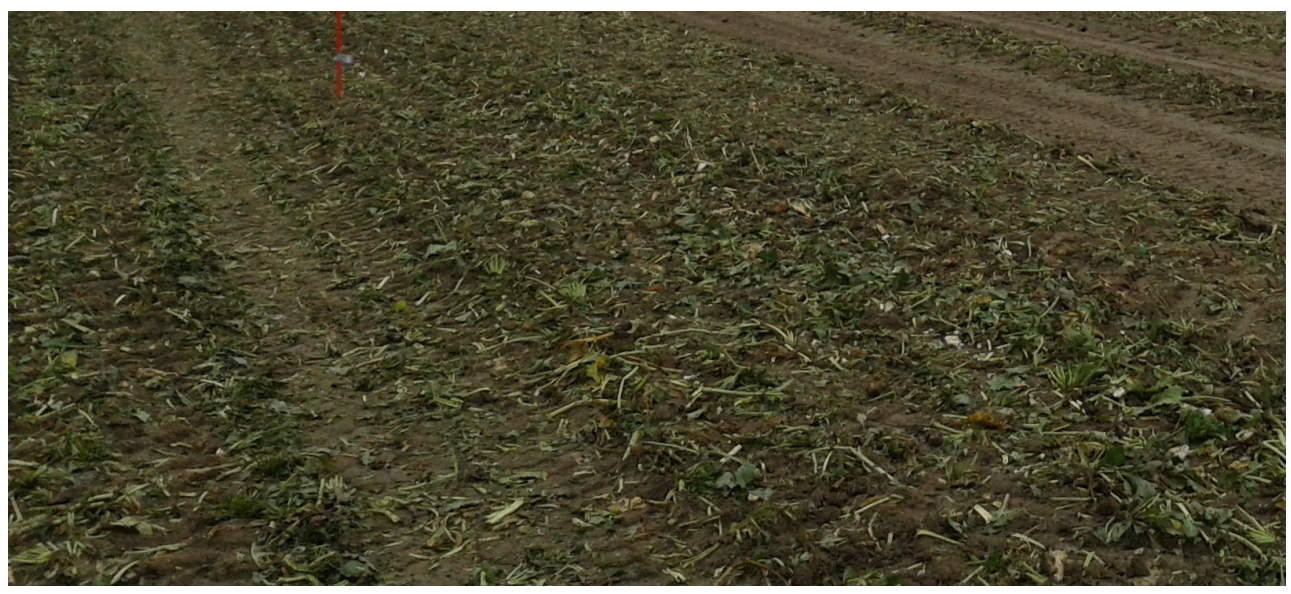

Fig. 1. Harvest residues, sugar beets

The measurement was carried out on limited portions of a plot size of $100 \times 50 \mathrm{~m}$. Undisturbed soil samples were taken. Kopecky cylinders were used with the volume $100 \mathrm{~cm}^{3}$. Samples were taken from three depths. The set for the measurement was the wheeled tractor New Holland T7050, which trailed the cultivator Köckerling Vario 480 with a working width of 4.8 meters with 37 tine pull and the track tractor John Deere 8320 RT. The track tractor John Deere was a source of the pulling power (Fig. 2).

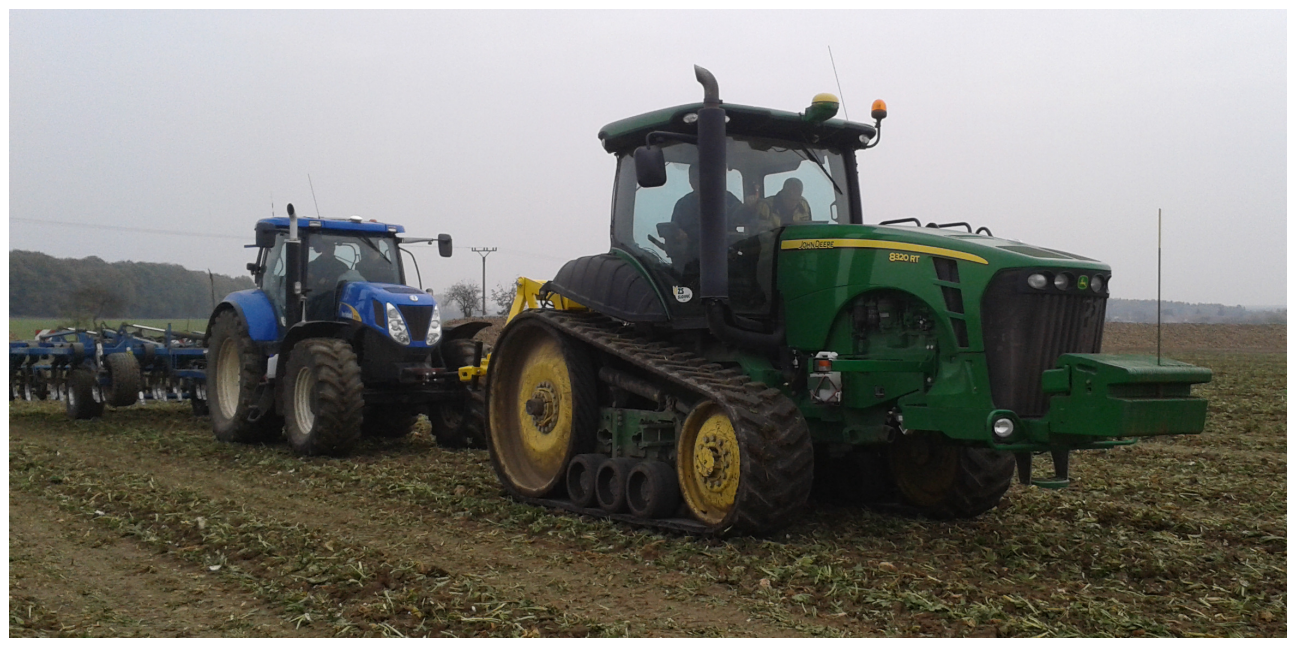

Fig. 2. Testing set. From the right: track tractor JD $8320 \mathrm{~T}$, special tool for measurement of draught force and tractor $\mathbf{N H ~} 7050$ pulling cultivator with tines

Load cell S-38 gauge was the main measurement component (with the range up to $200 \mathrm{kN}$ ). The description could be found at [2]. The testing frame is shown in Fig. 3. The frame location was between the tractors. For control a standard measurement device (rod with load cell) was used. . The frame has a hitch for the measurement machine (3) and a sensor for the draught force (4). 


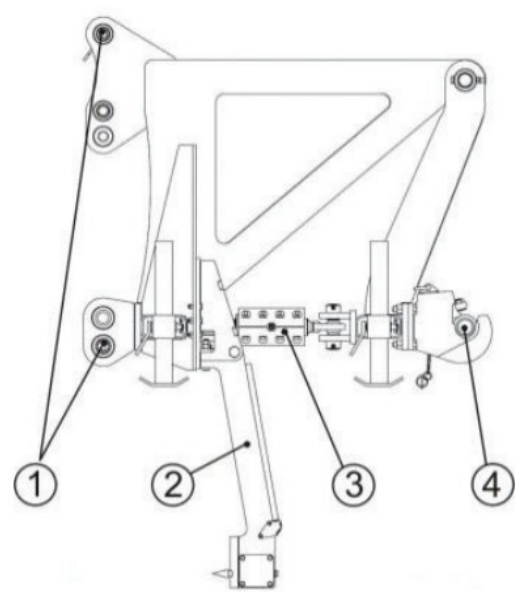

Fig. 3. Testing frame: 1 - three point hitch, which is connect to tractor (cat. 3); 2 - horizontal devices for measurement cone index; 3 - draught force sensor; 4 - hitch for measurement machine [3]

The measurement of the tensile force was performed by two basic methods. The first method for measuring the tensile force was assembled kit pair of tractors connected to the measuring device. It used a measuring rod with a sensor. The second tractor did not have gear and had releasing the wheel. The tractor New Holland served only to harness the combinator. In the second method of the measurement, the measuring devices (see Fig.3) have linked the John Deere track tractor-drawn combinator.

The working depth $0.15 \mathrm{~m}$ and the working speed of $6 \mathrm{~km} \mathrm{~h}^{-1}$ were chosen. Setting speed was monitored using GPS. After completion of the test (all passes) the upper soil profile was uncovered to determine the quality parameters of the tillage by the chosen cultivator.

The measuring frame has a horizontal penetrometer. For control this device used the registration penetrometer PN-10, which was constructed at the Czech University of Life Sciences in Prague. The angle of cone is $30^{\circ}$. The probe has a plane of $100 \mathrm{~mm}^{2}$. The measurements were performed at 200 places up to $0.4 \mathrm{~m}$ depth. The cone index was measured for each $40 \mathrm{~mm}$. All measurements were performed at the same depth.

\section{Results and discussion}

Fig. 4 shows a comparison of the two tensile forces of the measured values of strain gauges on the frame and on the rod at an average driving speed kit $6.24 \mathrm{~km} \cdot \mathrm{h}^{-1}$.

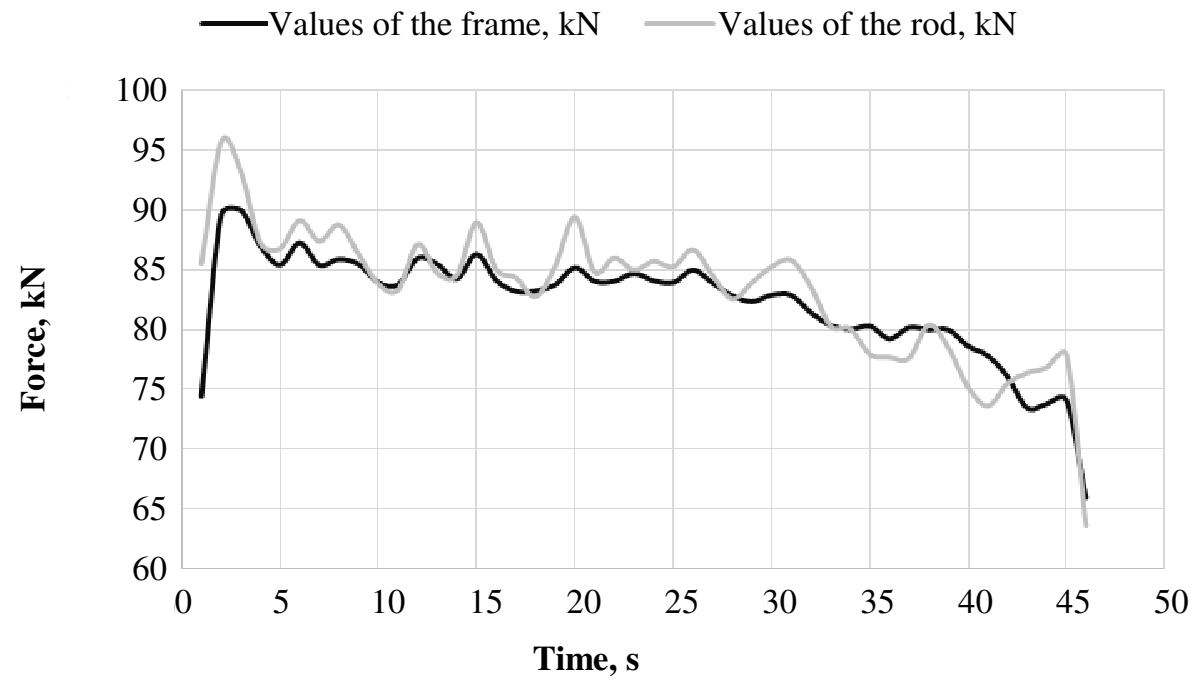

Fig. 4. Comparison of tensile forces on the frame and the rod 
Error, or deviation values, is in the sequence of measurements within tolerance. The average value of the error is $0.5 \%$.

Fig. 5 shows the progress of the penetration resistance depending on the depth. This progress was measured by the vertical penetrometer PN 10. Fig. 6. shows the measurement of the cone index by the vertical and horizontal penetrometer.

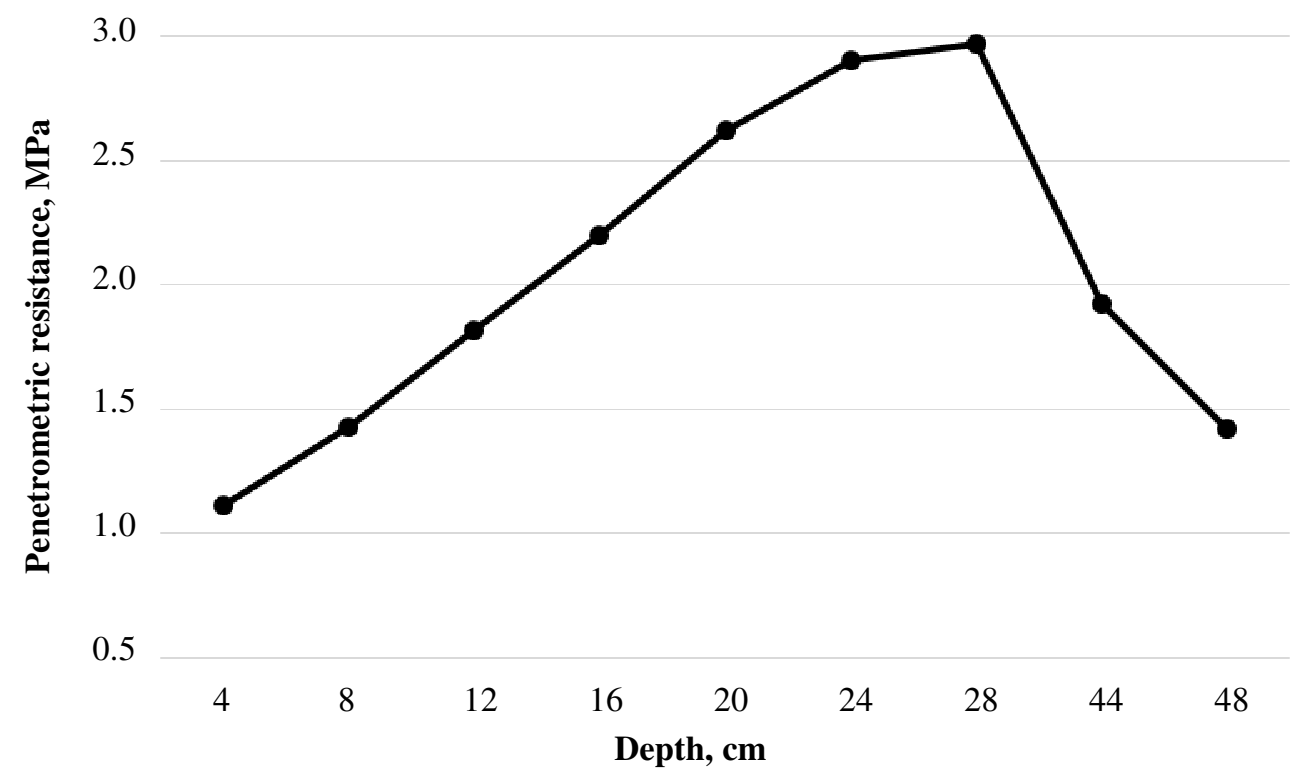

Fig. 5. Cone index- vertical penetrometer

During the horizontal measurements ——During the vertical measurements

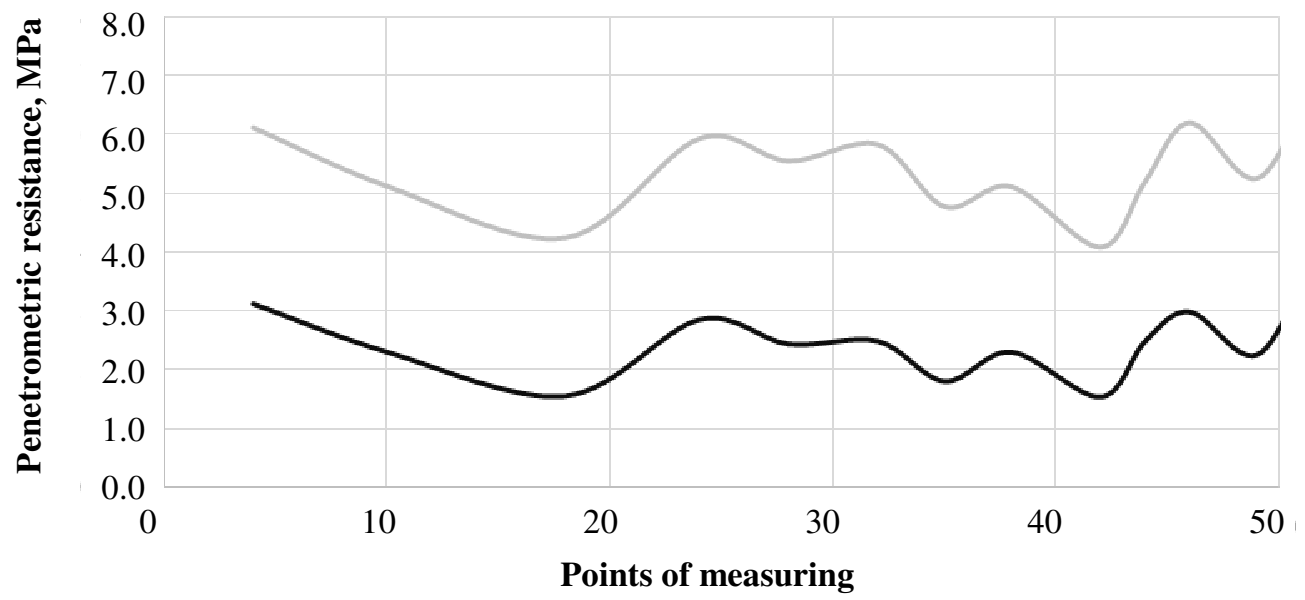

Fig. 6. Comparison of vertical and horizontal penetrometer

Horizontal penetration resistance at the marked plot varies from 3 to $4 \mathrm{MPa}$ at an approximate depth of $0.2 \mathrm{~m}$. Unfortunately, the measurement failed to make a comparison with less moist soil, so we cannot from these graphs accurately determine whether the penetration resistance was mainly affected by the soil moisture. However, we can say that with increasing the depth the cone index grows (Fig. 5). The horizontal measurement method achieves higher values of resistance than the vertical measurements (Fig. 6), which decides upon the type of tillage. Furthermore, we can say that speed does not affect the cone index. This is relatively surprising.

The Fisher test results are shown in Table 1. The results show a statistically significant difference between the measurements of both penetrometers. However, the data flow shows the same dependence for both methods of the measurement. 
Results of Fisher LSD test - homogenous groups

Table 1

\begin{tabular}{|c|c|c|c|}
\hline \multicolumn{4}{|c|}{ LSD test; Cone index, Mpa } \\
\hline Tupe of penetrometer & $\begin{array}{c}\text { Cone index } \\
\text { average, MPa }\end{array}$ & $\mathbf{1}$ & $\mathbf{2}$ \\
\hline Vertical penetrometer & 2.36 & $* * * *$ & - \\
\hline Horizontal penetrometer & 5.30 & - & $* * * *$ \\
\hline
\end{tabular}

Similar measurements were obtained by other authors. The results of this study confirm Novák et al. [2]. McLaughlin and Burtt [4] results emphasizing the influence of moisture. Other authors describe the influence of soil physical properties [3]. Subsequent research will lead toward improving the calibration of the measuring frame in terms of force transmission.

\section{Conclusions}

The tensile force has considerable influence on the development and construction of machines for soil tillage. The measured data are the basis for theoretical calculations for the construction of machine frames and working tools. The measurements showed the possibility of direct measurement of the draught force with the use the frame. There was no significant difference between the bar measurement and frame measurement (tensile force measurement). Measurements by both methods can be considered like the same. So, there is no need to use a second tractor, as with traditional methods. The horizontal penetrometer measurements may to some extent replace the classic penetrometer in vertically direction. There was a constant difference between the cone index values, which was determined by the measurement method. However, the data characteristics were the same for the horizontal and vertical penetrometers.

\section{Acknowledgements}

Supported by the CULS Prague - Project no. 2015:31160/1312/3110 and the project IGA no. 2017:31160/1312/3117.

\section{References}

1. Adamchuk V.I., Ingram T.J., Sudduth K.A., Chung S. O., Ingram T. J. On the go mapping of soil mechanical resistance using a linear depth effect model. Trans. ASABE, vol. 51, no. 6, 2008, pp. 1885-1894.

2. Novák P., Chyba J., Kumhála F., Procházka P. Measurement of stubble cultivator draught force under different soil conditions. Agron. Res., vol. 12, no. 1, 2014, pp. 135-142.

3. Procházka P., Novák P., Chyba J., Kumhála F. Evaluation of measuring frame for soil tillage machines draught force measurement. Agron. Res., vol. 13, no. 1, 2015, pp. 186-191.

4. McLaughlin N.B., Burtt S.D. Spatial mapping of tillage energy. Proc. 5th Int. Conf. Precis. Agric. Bloom. Minnesota, USA, 16-19 July, 2000, pp. 1-14.

5. Kheiralla A., Yahya A., Zohadie M., Ishak W. Modelling of power and energy requirements for tillage implements operating in Serdang sandy clay loam, Malaysia. Soil Tillage Res., vol. 78, no. 1, Jul. 2004, pp. 21-34.

6. Chen Y., Munkholm L.J., Nyord T.A discrete element model for soil-sweep interaction in three different soils. Soil Tillage Res., vol. 126, Jan. 2013, pp. 34-41.

7. Rooney, D. J., Lowery, B. A profile cone penetrometer for mapping soil horizons. Soil Sci. Soc. Am. J., vol. 64, no. 6, 2000, p. 2136.

8. Raper, R. L., Washington, B. H., Jarrell, J. D. Technical notes: a tractor-mounted multiple-probe soil cone penetrometer. Appl. Eng. Agric., vol. 15, no. 4, 1999, pp. 287-290. 